\title{
ТЕОРЕТИЧНІ АСПЕКТИ ПРОЦЕСУ ОБЛІКОВО-АНАЛІТИЧНОГО ЗАБЕЗПЕЧЕННЯ СТРАТЕГІЧНОГО ПЛАНУВАННЯ
}

\begin{abstract}
Анотація. У статті актуалізовано теоретичні аспекти обліково-аналітичного забезпечення стратегічного планування. На основі стратегічного планування проаналізовано динаміку кількості підприемств, які впроваджують інноваційну діяльність. Досліджено положення нормативно-правових актів щодо забезпечення стратегічного планування. Проведено аналіз останніх досліджень та публікацій вчених стосовно цієї теми та на їх основі виокремлено основні підходи до трактування сутності процесу обліково-аналітичного забезпечення стратегічного планування. Систематизовано основні етапи процесу стратегічного планування. Виділено чинники, що впливають на місію підприемства та сформовано їх основні об’екти обліку, а саме: рівень сукупної пропозиції, рівень сукупного попиту, наявність товарів-аналогів (замінників), управлінський досвід керівників, платоспроможність населення, податкова політика, субсидії та дотації підприемства, дивідендна політика тощо. Розроблено пріоритетні напрямки вдосконалення щодо здійснення стратегічного планування та управління.
\end{abstract}

Ключові слова: стратегія, стратегічне планування, обліково-аналітична система, місія, стратегічні цілі, SWOT-аналіз, PEST-аналіз.

Fatenok-Tkachuk Alla, Ploskina Andriana Lesya Ukrainka Volyn National University

\section{THEORETICAL ASPECTS OF THE PROCESS OF ACCOUNTING AND ANALYTICAL SUPPORT IN STRATEGIC PLANNING}

Summary. The article actualizes the theoretical aspects of accounting and analytical support in strategic planning. The dynamics of the number of enterprises which implement innovative activities is analysed from the perspective of strategic planning. The cases of regulations on ensuring the strategic planning are studied. The necessity of using the system of strategic accounting is grounded. The main stages of the strategic planning process and therefore the objects of accounting are classified. There are such stages of the strategic planning process: the establishment of the mission, definition of goals and objectives, internal and external analysis, formation of alternative strategies, finding the most effective strategy and its realization, evaluation of the implemented strategy. The analyses of the last researches and publications of scientists on this topic are carried out. The concept of accounting and analytical support in strategic planning is generalized and the main approaches to interpretation of the process of accounting and analytical support in strategic planning are defined. The factors that affect the mission of the enterprise are pointed out and the main objects of accounting are developed. They are the level of aggregate supply, the level of aggregate demand, presence of analogous goods (substitutes), managerial experience of authorized people, taxability of the population, fiscal policy, subsidies and dotations of the enterprise, dividend policy, the number of concluded contracts, payables and receivables, the number of employees and their qualification. The main elements included in the strategic planning are defined. The main elements included in the strategic planning are defined. The main reasons that prevent the usage of strategic planning in domestic enterprises are identified. They are as follows: managerial mistakes, inconsistency of the management system with the requirements of the modern market environment, lack of experience, the use of strategic planning methods that are in foreign practice but are not adapted to the domestic market. Priority areas for improvement have been developed and their implementation can improve the strategic planning in Ukraine.

Keywords: strategy, strategic planning, accounting and analytical system, mission, strategic goals, SWOTanalysis, PEST-analysis.

$\Pi^{2}$ остановка проблеми. На сучасному етапі розвитку економіки діяльність будьякого підприемства неможлива без стратегічного планування. Ця фрункція стратегічного управління передбачає здійснення процесу прийняття управлінських рішень щодо стратегічного фрормування місіі, ефрективного розподілу наявних ресурсів та швидкої адаптації підприемства до змін зовнішнього та внутрішнього середовища. Щоб не зазнавати значних втрат, підприемствам необхідно точніше прогнозувати майбутне діяльності підприемства, передбачувати багато варіантів розвитку ринку, розробляти відповідні варіанти розвитку. Тому, в сучасних умовах детальна розробка стратегічних планів стала як ніколи необхідною та актуальною. Неповна обгрунтованість основних підходів щодо трактування сутності процесу обліково-аналітичного забезпечення стратегічного планування зумовлюе потребу в конкретизації нормативних та теоретичних понять.

Аналіз останніх досліджень і публікацій. Значна кількість вітчизняних та зарубіжних вчених присвячували свої наукові праці теоретичним та методологічним аспектам стратегічного планування розвитку підприемства. Так, наприклад, проблеми формування стратегій підприемств знайшли своє відображення у працях таких учених як Чандлер А. [1] та Куїнн Дж. Б. [2]; проблеми сутності та практики стратегічного планування $є$ предметом досліджень багатьох вітчизняних та зарубіжних вчених, зокрема Кос- 
тецька Н. I. [3], Сомов Д. О. [4] та Свидрук I. I. [5]; сутнісними характеристиками процесу обліково-аналітичного забезпечення займались такі вчені як: Часовнікова Ю. С. [6], Нагірська К. С. [7], Гільмиярова М. Р. [8], Краснікова Н. Г. [9], Міценко Н. Г. [10] та інші; питання розвитку зовнішньоекономічної діяльності підприемства та особливості його стратегічного планування досліджувала Фатенок-Ткачук А. О. [11].

Виділення не вирішених раніше частин загальної проблеми. Багато науковців вважають, що до сьогоднішнього дня питання однозначного розуміння сутності стратегічного планування, процесу обліково-аналітичного забезпечення стратегічного планування та використання пов'язаних 3 ним термінів все ще залишається невирішеним. Такий стан викликає труднощі у проведенні досліджень стратегічного планування та впровадженні його у практику. Також, питання щодо етапів стратегічного планування та об'єктів їх обліку не є чітко структурованими, тому все ще залишаються відкритими та потребують вирішення.

Мета статті. Мета даної роботи полягає у тому, щоб обгрунтувати теоретичні аспекти облікового супроводу системи обліково-аналітичного забезпечення стратегічного планування, розкрити суть понять стратегія, стратегічне планування, проаналізувати праці вітчизняних вчених і на їх основі узагальнити сутність обліково-аналітичного забезпечення стратегічного планування, структурувати етапи стратегічного планування спрямованого на збільшення ефективності діяльності підприемств.

Виклад основного матеріалу. Стан стратегічного планування в Україні досить низький. Згідно 3 опитуванням, яке провела ФатенокТкачук А. О. 67 \% осіб, які приймали участь у анкетуванні зазначають про відсутність стратегічного планування на їхніх підприемствах [11]. Для порівняння, на рис. 1 ми згрупували інформащію щодо кількості підприемств, які впроваджують інноващіі. Помітна тенденція до зменшення інноваційно-активних підприемств. Із 2015 року спостерігається значне зниження кількості промислових підприемств, що впроваджували інноващї майже вдвічі. Стан залишаеться доволі стабільним, але 3 незначними коливаннями до 2019 року. Відповідно, незважаючи на необхідність та значні переваги використання стратегічного планування, багато підприємств нехтують такою можливістю, тим самим збільшують ризики недоотримання максимально можливого прибутку.

Базою для стратегічного планування є стратегія. Поняття «стратегія» у вузькому розумінні трактують як план дій, що розрахований на довгостроковий термін. Аналізуючи визначення багатьох науковців, ми узагальнили зміст цього поняття. Тобто, стратегія - це план, що розрахований на довготривалий період часу, який містить кількісні та якісні рішення щодо формування місії, довгострокових цілей, ефрективного використання стратегічних ресурсів та можливостей, усунення слабких сторін, здійснення заходів для захисту підприемства від небезпек зовнішнього середовища для отримання максимального прибутку в майбутньому. Стратегічне планування це процес формування стратегії, визначення місії, мети, довгострокових цілей підприемства, підбір ефрективних методів їх досягнення за рахунок ефрективного використання стратегічних ресурсів та швидкої адаптації підприемства до мінливого зовнішнього середовища.

Саме завдяки стратегічному плануванню підприемство визначає сукупність проблем, що пов'язані із необхідністю впровадження інноваційних технологій, розширення товарного асортименту, удосконалення структури управління підприемством, якісної перекваліфрікації персоналу та підвищення ефрективності використання кадрових ресурсів. Щоб прийняти обдумане стратегічне рішення потрібно зібрати всю необхідну для цього інфрормацію. Саме для цього використовують систему стратегічного обліку.

Ми здійснили грунтовне дослідження пращь таких науковщів, як Костецька Н. I. [3], Часовнікова Ю. С. [6], Нагірська К. Є. [7], Гільмиярова М. Р. [8], Краснікова Н. Г. [9], Міценко Н. Г. [10] та згрупували основні підходи до трактування сутності процесу обліково-аналітичного забезпечення

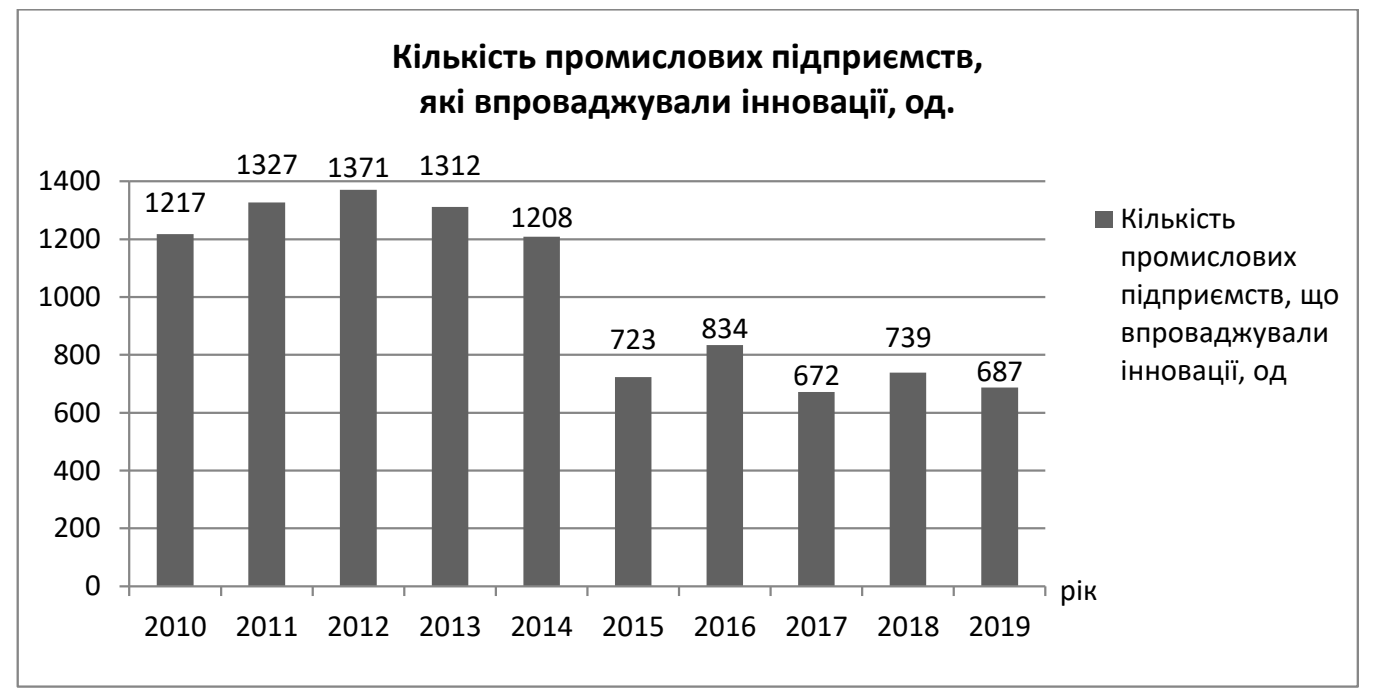

Рис. 1. Динаміка кількості підприемств, які впроваджують інноваційну діяльність 
стратегічного планування у вигляді таблиці 1. В підсумку даного дослідження, ми схиляемось до того, що обліково-аналітичне забезпечення стратегічного планування являе собою поєднання систем стратегічного аналізу, обліку та контролю, що упорядковує інформацію, яка в свою чергу аргументуе вибір бізнес-стратегій, координуе напрямки стратегічного розвитку підприемства, узагальнюе ефрективність реалізації оперативнотактичних та стратегічних управлінських рішень.

Основними нормативно-правовими документами, що регулюють процес стратегічного планування $є$ проект Закону «Про державне стратегічне планування», наказ Міністерства економічного розвитку і торгівлі України «Про затвердження Методичних рекомендацій щодо розроблення планів діяльності головних розпорядників бюджетних коштів на плановий та два бюджетні періоди, що настають за плановим», Стратегічний план діяльності Міністерства розвитку економіки, торгівлі та сільського господарства України на 2020-2024 роки.
Стратегічне планування як щілісний процес включае такі складники, як аналіз завдань, формування мети, розробка стратегій, контролювання за реалізацією стратегічного плану та здійснення його оцінки на основі значущих показників.

При стратегічному плануванні досить важливим рішенням підприемства $є$ вибір його місії. Це $є$ першим етапом цього складного процесу. В загальному, місія - це основне призначення підприємства, що характеризується чітко обумовленими причинами його існування та визначає головні напрямки та орієнтири його діяльності. На їі формування впливають зовнішні та внутрішні чинники (рис. 2).

На цьому етапі об'єктами обліку виступають цінності підприємства, фрілософія його існування, імідж підприемства, орієнтація на вітчизняні та іноземні ринки, потреби, які підприемство має задовольнити тощо.

На другому етапі здійснюеться визначення щілей та завдань організації. В порівнянні з місією,

Основні підходи до трактування сутності процесу

Таблиця 1 обліково-аналітичного забезпечення стратегічного планування

\begin{tabular}{|c|c|c|c|}
\hline № & Автор & Тлумачення сутності & Функціональний підхід \\
\hline 1 & 2 & 3 & 4 \\
\hline 1. & $\begin{array}{c}\text { Костецька Н. I. } \\
\text { [3] }\end{array}$ & $\begin{array}{l}\text { Обліково-аналітична система - це } \\
\text { інтегрована система прийомів обліково- } \\
\text { аналітичного забезпечення } \\
\text { менеджменту шляхом здійснення } \\
\text { специфічних внутрішньо-системних та } \\
\text { загальносистемних фрункцій. }\end{array}$ & $\begin{array}{l}\text { Основними фонкціями обліково- } \\
\text { аналітичного забезпечення } \\
\text { стратегічного планування є: } \\
\text { контрольна, регулятивна, внутрішньої } \\
\text { координації, адаптації до змін } \\
\text { зовнішнього середовища. }\end{array}$ \\
\hline 2. & $\begin{array}{c}\text { Часовнікова Ю. С. } \\
{[6]}\end{array}$ & $\begin{array}{l}\text { Обліково-аналітична система базуеться } \\
\text { на даних бухгалтерського обліку, } \\
\text { включаючи оперативні дані і використовуе } \\
\text { для економічного аналізу статистичну, } \\
\text { виробничу та довідкову та інші види } \\
\text { інформаціі. }\end{array}$ & $\begin{array}{l}\text { Основні джерела стратегічної } \\
\text { інформації поділяються на } 2 \text { види: } \\
\text { внутрішні та зовнішні. Інформація } \\
\text { різного роду необхідна на кожному } \\
\text { етапі стратегічного планування. }\end{array}$ \\
\hline 3. & $\underset{[7]}{\text { Нагірська К. Є. }}$ & $\begin{array}{l}\text { Обліково-аналітичне забезпечення являе } \\
\text { собою інтегровану систему стратегічного } \\
\text { обліку і стратегічного аналізу, яка } \\
\text { систематизуе індрормацію для обгрунтування } \\
\text { бізнес-стратегії, координації напрямів } \\
\text { стратегічного розвитку підприємства, } \\
\text { системної оцінки ефективності реалізащї } \\
\text { оперативно-тактичних і стратегічних } \\
\text { управлінських рішень. }\end{array}$ & $\begin{array}{l}\text { Узагальнено три основні складники } \\
\text { обліково-аналітичного забезпечення: } \\
\text { обліку, аналізу та контролю. } \\
\text { Керівники приймають управлінські } \\
\text { рішення орієнтуючись на поставлені } \\
\text { цілі підприемства (тактичні, стратегічні } \\
\text { та оперативні). }\end{array}$ \\
\hline 4. & $\begin{array}{c}\text { Гільмиярова М. Р. } \\
\text { [8] }\end{array}$ & $\begin{array}{l}\text { Обліково-аналітичне забезпечення - } \\
\text { концептуальна модель, що складається із } \\
\text { взаємопов'язаних обліково-аналітичних } \\
\text { процедур та застосовується для } \\
\text { забезпечення апарату управління } \\
\text { корпорації необхідною індрормацією. } \\
\end{array}$ & $\begin{array}{l}3 \text { цього тлумачення випливає одна із } \\
\text { функщй планування, що характеризуе } \\
\text { прийняття керівниками ефективних } \\
\text { управлінських рішень на базі достовірних } \\
\text { інформаційних даних для здійснення } \\
\text { стратегічного планування підприємства. } \\
\end{array}$ \\
\hline 5. & $\begin{array}{l}\text { Краснікова Н. Г. } \\
{[9]}\end{array}$ & $\begin{array}{l}\text { Механізм обліково-аналітичного } \\
\text { забезпечення передбачає збирання } \\
\text { індормації, способи їі узагальнення та } \\
\text { аналізу, а також технології надання } \\
\text { безпосереднім користувачам з метою } \\
\text { оцінки рівня та стану економічної безпеки } \\
\text { власного підприємства чи його партнерів } \\
\text { та/або конкурентів, діяльність яких може } \\
\text { вплинути на стан безпеки підприемства. }\end{array}$ & $\begin{array}{l}3 \text { огляду сутності цього поняття можна } \\
\text { визначити мету обліково-аналітичного } \\
\text { забезпечення стратегічного } \\
\text { планування, яка полягає у тому, щоб } \\
\text { забезпечувати необхідною інформацією } \\
\text { керівників, конкурентів та інших } \\
\text { користувачів для стабілізації безпеки } \\
\text { підприємства. }\end{array}$ \\
\hline 6. & $\begin{array}{c}\text { Міценко Н. Г. } \\
{[10]}\end{array}$ & $\begin{array}{l}\text { Обліково-аналітична інформація } \\
\text { представляє собою економічну модель } \\
\text { взаємозв'язку між системою економічної } \\
\text { безпеки, інформаційним ресурсом, якої } \\
\text { вона є, та інфрормаційними процесами в } \\
\text { середині підприємства. }\end{array}$ & $\begin{array}{l}\text { Визначено сутність економічної } \\
\text { безпеки, як однієї із складових } \\
\text { обліково-аналітичної системи та їі } \\
\text { основні принципи та складові. }\end{array}$ \\
\hline
\end{tabular}




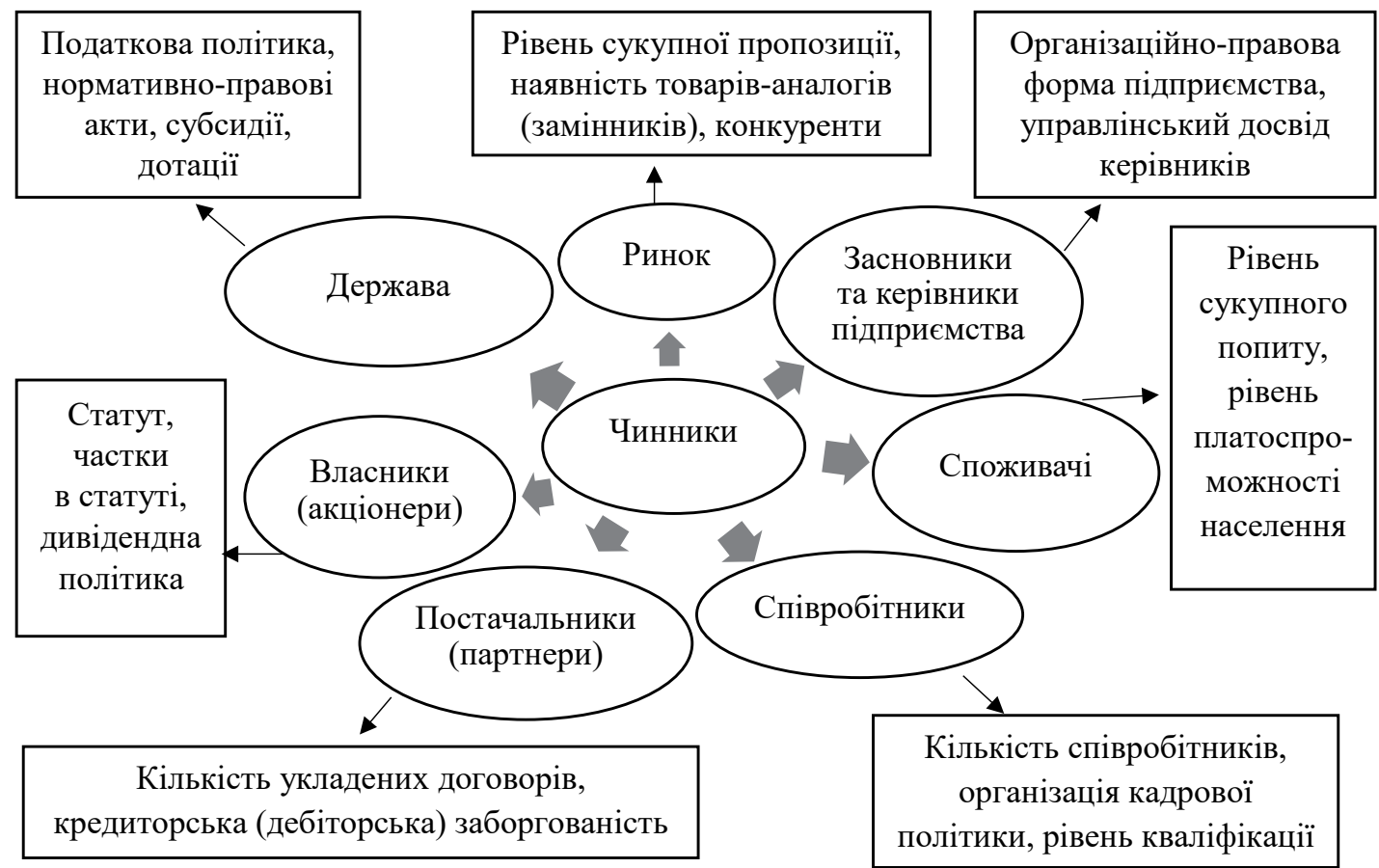

Рис. 2. Чинники, що впливають на місію підприемства та їх об'екти обліку

Джерело: розроблено авторами

цілі показують конкретні напрямки діяльності підприемства. На цьому етапі об’ектами обліку є рівень конкурентоспроможності продукції, кількість впроваджених інновацій, додаткові резерви підприемства, життевий цикл підприемства, обсяги реалізащії товару, витрат на виробнищтво продукщії тощо. На базі одніеї загальної цілі (мети, місіi) форомуються більш деталізовані одиничні цілі, стратегії, тактики та політики для того, щоб досягнути бажаний результат. Слід виділити три типи цілей: стратегічні (підвищення конкурентоспроможності товару, вихід підприемства на нові ринки збуту тощо), тактичні (перекваліфрікація кадрів, введення інноваційного продукту тощо) та оперативні (розробка та фінансування програми, збільшення доданої вартості продукції на 10 \% тощо).

Місія кожного підприемства є різною, саме вона і відрізняе організацію між іншими конкурентами. На шляху досягнення ціеї місії існуе безліч загроз та перешкод. Чим краще підприемство розрізняе небезпеки, тим більше шансів на досягнення бажаного результату. Тому наступним кроком стратегічного планування $€$ аналіз зовнішнього та внутрішнього середовища. Слід наголосити, що саме зовнішне середовище $є$ основним мотивом створення та реалізації стратегічних планів. Об'єктами виступають податкова політика держави, кон'юнктура окремих сегментів ринку, сощіально-політична ситуація в країні, кадрова політика підприємства, амортизаційна політика, рентабельність, фрінансова стійкість, платоспроможність тощо. Цей аналітичний етап часто супроводжується проведенням SWOT-аналізу та PEST-аналізу.

Наступним кроком у процесі стратегічного планування $є$ форомування набору альтернативних стратегій. Стратегї розробляються на вищому рівні управління [13, с. 84]. На цьому етапі треба здійснити оцінку альтернативних шляхів діяльності підприемства та вибрати найопти- мальніші з них варіанти. Основними об'єктами обліку будуть виступати показники розвитку підприемства. На щій основі вище керівництво приймає рішення, яку стратегію доцільніше обрати. На це рішення впливає багато фракторів, наприклад досвід минулих стратегій, фрактор часу, ступінь ризику, очікувана ефективність, думка власників та керівників тощо.

Реалізація стратегії завершується їі оцінкою. Це і буде завершальний етап стратегічного планування. Тут важливо перевірити правильність відбору методів внутрішнього та зовнішнього аналізу, виявити відповідність наявних показників діяльності підприемства до очікуваних.

Висновки і пропозиції. Отже, стратегічне планування в Україні є не достатньо розвиненим. Це пов'язано 3 деякими помилками управлінців, невідповідністю управлінської фрілософрї до вимог сучасного ринкового середовища, відсутністю досвіду керівників, а також з тим фрактом, що методи стратегічного планування, які є широко використовуваними у зарубіжній практиці, не адаптовані до нашого вітчизняного ринку i, тому результати використання не завжди задовільні. У зв'язку з цим, ми виділили пріоритетні напрямки вдосконалення щодо здійснення стратегічного планування та управління:

- використання послуг фрахівців із розробки стратегії, формування конкурентних переваг та ін.;

- проведення якісного аналізу всіх галузей підприємства;

- встановлення конкретних термінів виконання стратегічних і тактичних цілей;

- проведення ретельного контролю над едективним розподілом ресурсів;

- використання сучасних інструментів та підходів до формування стратегії та її реалізації;

- збільшення переліку документів, що регламентують процес стратегічного планування; 
- введення нових документів, які будуть базою для планування діяльності підприемства;

- нормативно-правове забезпечення чіткої та прозорої процедури розроблення документів стратегічного напряму.

Також, ми вважаємо, що досить перспективним підходом до формування обліково-аналі- тичного забезпечення стратегічного планування підприемства є інтеграція всіх наявних на підприемстві видів облікової діяльності 3 процедурами попередньої аналітичної обробки первинних даних, набутками дисципліни менеджменту знань й принципами ситуаційного управління.

\section{Список літератури:}

1. Chandler Alfred D. Jr. Strategy and Structure: Chapters in the History of the American Industrial Enterprise: MIT Press. 1998.

2. Минцберг Г., Куинн Дж. Б., Гошал С. Стратегический процесс. Питер, 2001. 274 с.

3. Костецька Н.І. Стратегічне планування діяльності підприемств: теоретичні аспекти. Інноваційна економіка. 2020. № 7-8 (85). C. 65-71.

4. Сомов Д.О. Стратегічне управління системою стійких конкурентних переваг підприемства. Бізнес Інфборл. 2015. № 4. С. 273-278.

5. Свидрук I.I. Передумови стратегічного планування інноваційного розвитку підприемств. Bicник Tернопільського національного еконолічного університету. 2020. № 2(96). С. 24-35.

6. Часовнікова Ю.С. Система обліково-аналітичного забезпечення управління підприемством. Сучасні проблеми управління підприєлствали: теорія та практика: матеріали міжнар. наук.-практ. конф., (Харків, 3-4 берез. 2020 р.). Харків : ФОП Панов А. М., 2020. С. 440-442.

7. Нагірська К.Є. Обліково-аналітичне забезпечення вибору стратегії підприемства: систематизація наукових поглядів. Еконолічні науки. Серія : «Облік і бінанси». 2015. № 12. С. 206-215.

8. Гильмиярова М.Р. Концептуальная учетно-аналитическая модель денежных потоков корпоративных структур. 2015. URL: http://doc.knigi-x.ru/22ekonomika/84577-1-udk-6576-gilmiyarova-konceptualnaya-uchetnoanaliticheskaya-model-denezhnih-potokov-korporativnih.php (дата звернення: 26.03.2021).

9. Краснікова Н.Г. Шляхи вдосконалення обліково-аналітичного забезпечення діяльності комунальних некомерційних підприємств охорони здоров’я. Бізнес Інфборлм. 2020. № 9. С. 212-218.

10. Міценко Н.Г., Ціцяла А.С. Стратегічний аспект розвитку підприемства. Стратегія підприємства: підприємницький контекст : зб. матеріалів Міжнар. наук.-практ. конф. Київ : КНЕУ, 2017. С. 49-51.

11. Фатенок-Ткачук А.О., Ліпич Л.Г. Формування стратегії розвитку зовнішньоекономічної діяльності машинобудівних підприемств : монографія. Луцьк : Волин. нац. ун-т ім Лесі Українки, 2010. 220 с.

12. Грудцина Ю.В. Інноваційна діяльність в Україні: аналіз та прогнозування. Бізнес Інфборл. 2019. № 2. С. $78-84$.

13. Фатенок-Ткачук А.О. Організація обліково-аналітичного забезпечення процесу формування стратегії розвитку підприемства. Економічний часопис Східноєвропейського національного університету імені Лесі Украӥнки. Луцьк : Вежа-Друк, 2015. № 2. С. 82-90.

\section{References:}

1. Chandler Alfred D Jr. (1998) Strategy and Structure: Chapters in the History of the American Industrial Enterprise: MIT Press.

2. Mincberg G., Kuinn Dzh. B., Goshal S. (2001) Strategicheskij process [Strategic process]. Piter. (in Russian)

3. Kostetska N.I. (2020) Stratehichne planuvannia diialnosti pidpryiemstv: teoretychni aspekty [Strategic planning of enterprises: theoretical aspects]. Innovatsiina ekonomika, 7-8 (85), 65-71.

4. Somov D.O. (2015) Stratehichne upravlinnia systemoiu stiikykh konkurentnykh perevah pidpryiemstva [Strategic management of the system of stable competitive advantages of the enterprise]. Biznes Inform, 4, 273-278.

5. Svydruk I.I. (2020) Peredumovy stratehichnoho planuvannia innovatsiinoho rozvytku pidpryiemstv [Prerequisites for strategic planning of innovative development of enterprises]. Visnyk Ternopilskoho natsionalnoho ekonomichnoho universytetu, 2(96), 24-35.

6. Chasovnikova Yu.S. (2020) Systema oblikovo-analitychnoho zabezpechennia upravlinnia pidpryiemstvom [The system of accounting and analytical support of enterprise management]. Proceedings of the Suchasni problemy upravlinnia pidpryiemstvamy: teoriia ta praktyka (Ukraine, Kharkiv, March 3-4, 2020), Kharkiv: FOP Panov A. M.

7. Nahirska K.Ie. (2015) Oblikovo-analitychne zabezpechennia vyboru stratehii pidpryiemstva: systematyzatsiia naukovykh pohliadiv [Accounting and analytical support for the choice of enterprise strategy: systematization of scientific views]. Ekonomichni nauky. Seriia: "Oblik i finansy», 12, 206-215.

8. Hylmyiarova M.R. (2015) Konceptual'naja uchetno-analiticheskaja model' denezhnyh potokov korporativnyh struktur [Conceptual accounting and analytical model of cash flows of corporate structures]. Vestnik Pskovskogo gosudarstvennogo universiteta, 2, 44-48. Available at: http://doc.knigi-x.ru/22ekonomika/84577-1-udk-6576-gilmiyarova-konceptualnayauchetno-analiticheskaya-model-denezhnih-potokov-korporativnih.php (accessed 26 March 2021).

9. Krasnikova N.H. (2020) Shliakhy vdoskonalennia oblikovo-analitychnoho zabezpechennia diialnosti komunalnykh nekomertsiinykh pidpryiemstv okhorony zdorovia [Ways to improve the accounting and analytical support of communal non-profit health care enterprises]. Biznes Inform, 9, 212-218.

10. Mitsenko N.H., Tsitsiala A.S. (2017) Stratehichnyi aspekt rozvytku pidpryiemstva [Strategic aspect of enterprise development] Proceedings of the Stratehiia pidpryiemstva: pidpryiemnytskyi kontekst (Ukraine, Kyiv, November 16-17, 2017), Kyiv: KNEU, pp. 49-51.

11. Fatenok-Tkachuk A.O., Lipych L.H. (2010) Formuvannia stratehii rozvytku zovnishnoekonomichnoi diialnosti mashynobudivnykh pidpryiemstv [Formation of strategy of development of foreign economic activity of machinebuilding enterprises]. Lutsk: Volyn National University named after Lesya Ukrainka. (in Ukrainian)

12. Hrudtsyna Yu.V. (2019) Innovatsiina diialnist v Ukraini: analiz ta prohnozuvannia [Innovative activity in Ukraine: analysis and forecasting]. Biznes Inform, 2, 78-84.

13. Fatenok-Tkachuk A.O. (2015) Orhanizatsiia oblikovo-analitychnoho zabezpechennia protsesu formuvannia stratehii rozvytku pidpryiemstva [Organization of accounting and analytical support of the process of forming the strategy of enterprise development]. Ekonomichnyi chasopys Skhidnoievropeiskoho natsionalnoho universytetu imeni Lesi Ukrainky, 2, 82-90. 